In relating geomorphology to management of the environment this textbook offers a new approach to the study of the subject. It concentrates on such practical problems as soil erosion, flooding, landslides, and permafrost, and it includes many case studies. The book should interest students of agriculture, soil science, land management, land planning, geology, and civil engineering, as well as geomorphologists. $£ 8.00$ paper covers $£ 3.80$

\title{
Experimental Petrology
}

Basic Principles and Techniques

Alan D. Edgar

This book covers the basic principles and techniques used in experimental petrology and mineralogy, and it is intended primarily for research students in these and related sciences. Its main purpose is to describe the techniques and principles of operation of equipment now available for research into the conditions of formation of materials of the earth's crust and upper mantle. For readers wishing to pursue the subject at a more comprehensive level, extensive references are given to articles scattered throughout the geological, chemical and engineering literature. $\mathbf{£ 5 . 7 5}$

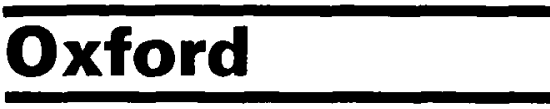




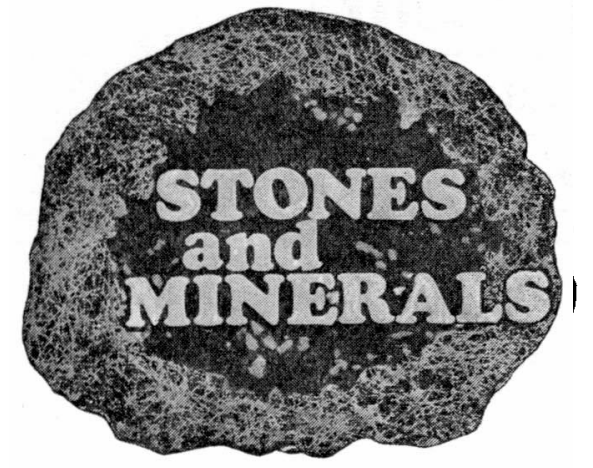

Walter

Schumann
Whether you are a 'hobby geologist, mineral collector, precious stone enthusiast; or one of the students, scientists, civil engineers, or professional geologists working with rocks and minerals, you will find this book invaluable - both on the reference shelf and for work in the field. Each type is dealt with thoroughly and, for the layman, there are clear definitions of all the terms used. Illustrated throughout with colour and black and white photographs and line drawings.

£2.95 net

Lutterworth

Press

\section{CAM B R I D G E JOUR NALS}

The Geological Magazine is one of 48 learned journals published by Cambridge University Press.

The 1974 descriptive catalogue of Cambridge journals with details of back volumes is available from the London and New York offices of the Press.

Cambridge Journals may be ordered from a bookseller or direct from the publishers.

\section{Cambridge University Press}

Bentley House, 200 Euston Road, London, NW1 2DB American Branch : 32 East 57th Street

New York, N.Y. 10022 


\section{NOTES FOR CONTRIBUTORS}

Contributions for publication should be addressed to The Editors, Geological Magazine, Sedgwick Museum, Downing Street, Cambridge, $\mathrm{CB}_{2}{ }_{3} \mathrm{EQ}$, England.

All contributions, whether articles, correspondence or reviews, must be typed in duplicate on one side of the paper, double spaced throughout, with a wide margin on the left of each page and a narrower margin on the right. Any minor corrections should be made neatly in the typescript, leaving the margins clear.

Articles must be accompanied by a brief summary. Contributions should follow the general style of papers in recent issues of the Magazine and the principles laid down in Notes to Authors (Proc. Geol. Soc. Lond., No. I627. Oct. I965). Headings should be set out clearly, but not underlined. Primary headings should be in lower case, at margin, with arabic numeral; sub-headings should be numbered 2.a, 2.b, etc., and tertiary headings 2.a.1., 2.a.2. No cross references should be given by page number, but 'above' and 'below' should be used with the section specified, e.g. Section 2.a.I. The total length of a paper should not in general exceed 20 pages of the Geological Magazine; preference and priority are given to short papers. The accuracy of references is the responsibility of authors. References must be double spaced and abbreviated in the form of the

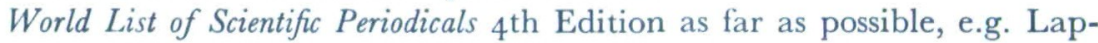
worth, C. I878. The Moffat Series. Q. $7 l$ geol. Soc., Lond. 34, 240-343. Books should be cited briefly as: Burns, R. G. I 970. Mineralogical applications of crystal field theory. 224 p., C.U.P., London. Unpublished work, e.g. from theses, should normally be referred to in the text in parentheses and not included in the reference list unless in the press.

Illustrations must be drawn to allow reduction to maximum size of I $65 \mathrm{~mm} \times$ I I $\mathrm{mm}$; originals must not exceed $495 \mathrm{~mm} \times 330 \mathrm{~mm}$ and must be sent in a flat package. Lettering must allow for legibility after reduction (i.e. equivalent to $\mathrm{I} \mathrm{mm}$ as a minimum on reduction). Duplicates of illustrations may be prints or, preferably, reductions. Metric units of the SI system are preferred. Illustrations in the text will be referred to as figures (Fig. 2, $2 a$, etc.), and halftone plates will be referred to (also in arabic) as Plates 2, 2a, etc. Folding plates will not be accepted. Captions for figures and plates must be typed on separate sheets.

Twenty-five offprints of each paper will be provided free of charge. Additional offprints may be purchased according to a set scale of charges. 


\section{Geological Magazine}

\section{Volume i i , Number 3, May 1974}

RICKARDS, R. B. \& KOREN', T. N.

Virgellar meshworks and sieular spinosity in Llandovery graptoloids

193-204

WINCHESTER, J. A.

The control of the whole-rock content of $\mathrm{CaO}$ and $\mathrm{Al}_{2} \mathrm{O}_{3}$ on the occurrence of the aluminium silicate polymorphs in amphibolite facies pelites

GREEN, C. P.

Pleistocene gravels of the River Axe in south-western England, and their bearing on the southern limit of glaciation in Britain

$213-220$

RAO, T. RAMAMOHANA

A bedded deposit of anthophyllite schist in the Precambrian belt of Nellore, South India

$221-228$

NAQVI, S. M., RAO, V. DIVAKARA, SATYANARAYANA, K. \& HUSSAIN, S. M.

Geochemistry of post-Dharwar basic dikes and the Precambrian crustal evolution of peninsular India

$229-236$

\section{GORRESPONDENCE}

I.U.G.S. Precambrian/Cambrian Boundary Working Group in Siberia, r 973 : J. W. Cowie \& A. Yu Rozanov

Tillite in the Togo formation in Ghana: J. S. Gaisie \& J. Winter 253-254

The function of conodonts: J. PRIDdLE

REVIEWS

$258-266$

PUBLICATIONS RECEIVED 